\title{
APORTUL IMAGISTICII ÎN DIAGNOSTICUL COMPLICAT⿱IILOR INTRACRANIENE SECUNDARE OTOMASTOIDITEI LA COPIL
}

\author{
Mariana Coman', Alexandru Coman², Dan-Cristian Gheorghe ${ }^{1,3}$, \\ Mihaela Bălgrădean ${ }^{1,3}$

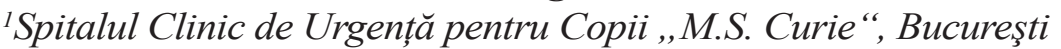 \\ ${ }^{2}$ Institutul de Fonoaudiologie şi Chirurgie Funcțională ORL „Prof. Dr. Hociotă“", Bucureşti \\ ${ }^{3}$ Universitatea de Medicină şi Farmacie ,, Carol Davila“, Bucureşti
}

\begin{abstract}
REZUMAT
Introducere. Otita medie (OM) acută este una dintre cele mai comune infecții diagnosticate în patologia copilului, cu evoluție autolimitată cel mai frecvent $(1,2)$. Ea poate duce în 2-6\% dintre cazuri (2) spre complicații supurative intracraniene cu evoluție nefavorabilă, fatală în 8-26,3\% din ele (2,3). Apariția semnelor neurologice în evoluția unei otite supurative necesită investigații imagistice de urgență (2-8).

Material şi metodă. Se prezintă cazul unei fetițe de 10 ani diagnosticată cu otită supurată complicată, transferată la Spitalul Clinic de Urgență pentru Copii „M.S. Curie“ Bucureşti în secția ORL după o evoluție a bolii de 2 săptămâni. Copilul se prezintă la internare cu: febră, otoree purulentă, semne neurologice reprezentate de cefalee, convulsii, redoare de ceafă. Se efectuează în urgență un examen computer tomografic (CT) cu substanță de contrast intravenoasă (iv).

Rezultat. Examenul CT, extins şi la nivel cervical evidențiază prezența unui proces litic la nivelul stâncii temporale şi soluție de continuitate între antrul mastoidian şi meninge, şi evidențierea unui abces epidural perisigmoidian, tromboza de sinus sigmoid extinsă la nivelul jugularei şi sinusului lateral, semne de meningită, cerebrită cerebeloasă, abces cerebral şi empiem subdural.

Concluzii. Complicațiile în infecțiile urechii medii sunt rare, însă apariția semnelor neurologice la examenul fizic impune un examen imagistic care poate preciza arhitectura locală, prezența complicațiilor locale sau la distanța pentru instituirea unui tratament adecvat şi rapid.
\end{abstract}

Cuvinte cheie: copil, otită medie, complicații, computer tomograf (CT)

\section{INTRODUCERE}

Otita medie este inflamaţia mucoasei urechii medii (cavitatea timpanică, antrul mastoidian, celulele mastoidiene şi tuba lui Eustachio) (6). Afecțiunea este determinată cel mai frecvent de agenți microbieni (haemophilus influenzae, streptococcus pneumoniae) $(2,7)$ mai rar de cei virali $(7)$, iar factorii favorizanți, la copii mici sunt reprezentați de: sistemul imunitar imatur, traiectul scurt orizontal şi larg al trompei lui Eustachio, prezența unui bogat țesut limfoid la nivelul nasofaringelui (5-11), iar la copiii mari: imuno-depresia sistemului imunitar congenitală sau secundară (ex: rujeola, tuberculoza, pertusis) (12), rinite alergice, astm, infecțiile tractului respirator superior $(11,12)$. Cele mai multe cazuri se vindecă spontan sau cu tratament simptomatic, altele dau perforația timpanului şi progresia spre otita cronică supurativă, iar o parte din acestea pot ajunge la complicații intracraniene $(1,13,14)$.

Folosirea antibioticelor pe scară largă în tratamentul otitelor medii a redus numărul complicațiilor $(8,9,14,15)$ dar a determinat selectarea unor tulpini rezistente, în anumite cazuri cu mascarea simptomatologiei şi diseminări meningo-encefalice $(4,8$, 15). Cele mai frecvente complicații sunt: meningita, abces intraparenchimatos, tromboflebita sinusului lateral, empiemul sub-dural şi epidural (4-14).

Mecanismul patogenic de pătrundere a procesului infecțios de la nivelul urechii medii, intra- 
cranian, este prin: căi preformate (conduct auditiv intern, apeductul cohleei, suturile osului temporal, pentru meningită şi colecții sub- şi epidurale) sau prin căi neoformate reprezentate de soluție de continuitate osoasă, apărută prin fenomene de osteită şi liza osoasă inflamatorie (meningita şi empiem subdural) (1-8). Altă cale de propagare a infecției este calea venoasă ce permite transportarea germenilor prin venulele mastoidiene urmată de afectarea rețelei venoase de calibru mai mare reprezentată de sinusul lateral şi sigmoid, vena emisară mastoidiană, vene corticale şi diploice (1-14). Acestea pot determina apariția tromboflebitelor de sinus lateral, meningo-encefalitelor, abcesului intraparenchimatos şi abceselor peri- sau subdurale (2-11).

Diagnosticul este suspectat în cazul asocierii semnelor neurologice şi infecțioase generale la un pacient cunoscut cu otită $(5,11)$, dar confirmarea este dată de examenul computer tomografic (CT) cu injectarea de contrast intravenos care permite stabilirea unui diagnostic pozitiv, topografia leziunilor şi aprecierea gravităţii complicațiilor (2- 15).

\section{PREZENTARE DE CAZ}

Prezentăm cazul unei fetițe de 10 ani cu otomastoidită supuratăşi multiple complicații intracraniene.

În antecedente fetița a prezentat mai multe episoade de otită acută, tratate ambulator, iar după un episod de infecție respiratorie intercurentă, tratată cu simptomatice şi antibiotic pe cale orală copilul prezintă: febră şi otalgie, motive pentru care este internată într-un spital local unde se instituie tratament antibiotic 3 zile. Sub tratament apar: cefalee, otoree, modificarea stării generale, motiv pentru care se transferă la spitalul județean unde se schimbă tratamentul antibiotic şi se practică timpanotomie. După alte 4 zile starea se agravează cu apariția convulsiilor, somnolenței, redoare de ceafă. Pacienta se transferă într-un serviciu de neuro-chirurgie, apoi în secția ORL a Spitalului Clinic de Urgență pentru copii „M.S. Curie“.

Examenul clinic evidențiază stare generală mediocră, tegumente palide, somnolență, sindrom meningeal prezent. La palpare se evidențiază tumefacție latero-cervicală stânga dureroasă la palpare.

Examenul otoscopic evidențiază conduct auditiv extern stâng cu secreții purulente, perforație timpanică prin care se elimină secreții muco-purulente abundente.

Examinarea CT craniu a fost efectuată nativ şi cu substanță de contrast iv, cu secțiuni de $5 \mathrm{~mm}$ (reconstrucții: în fereastra de parenchim cu $2,5 \mathrm{~mm}$; şi cu rezoluție înaltă centrate la nivelul stâncii temporalului, cu secțiuni de 1,25 mm), apoi după injectarea contrastului secvența $\mathrm{cu}$ reconstrucții axiale de $1,25 \mathrm{~mm}$ şi reconstrucții în planurile coronale şi sagitale.

Examenul CT evidențiază prezența unei cavități timpanice şi antrul mastoidian, lărgite cu pereți neregulați, conținut hipodens (Fig. A1), liza peretelui stâncii temporale spre posterior în zona de contact cu sinusul sigmoid (Fig. A2), prezența aerului în spațiul subdural (Fig. A3), un mic abces epidural adiacent cu priză de contrast marginală (Fig. A4).

Sinusul transvers (Fig. A6), sigmoid (Fig. A5), vena jugulară (Fig. A7) de partea stângă sunt trombozate cu un conținut hipodens şi mici bule aerice, cu priză de contrast la nivelul peretelui, fără opacifiere intralumenală, aspect lacunar, după administrarea contrastului iv.

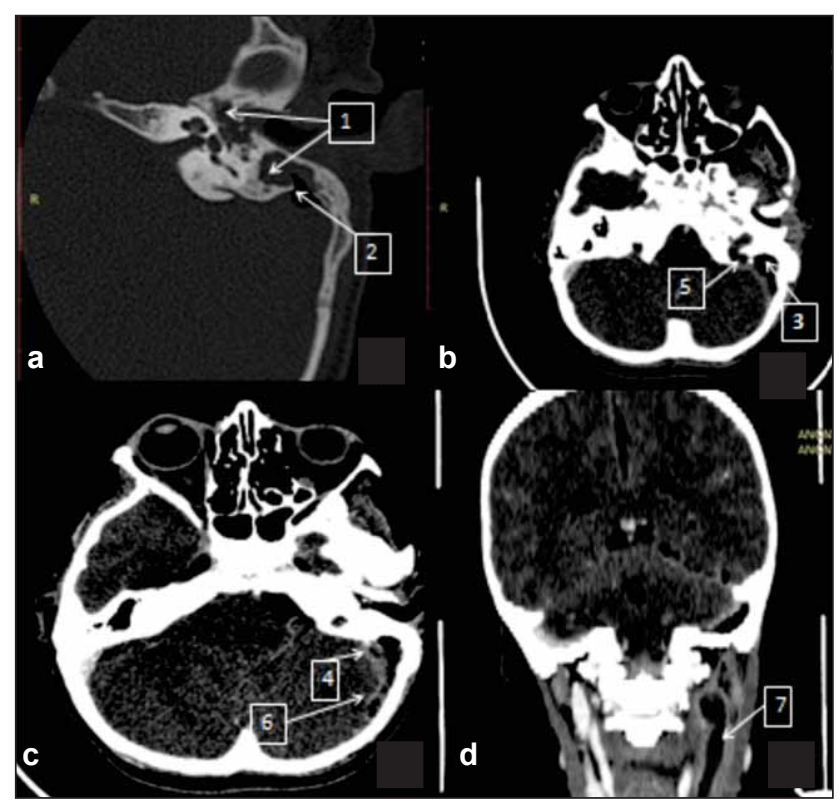

FIGURA 1A. Examinare CT craniană

a - examen nativ cu reconstrucție fină $1,25 \mathrm{~mm}$ şi rezoluție înaltă la nivelul stâncii temporale; $b, c$ - secțiuni axiale la nivelul fosei posterioare în fereastra de parenchim după administrarea substanței de contrast; $d$ - reconstrucții coronale la nivel cervical în planul vaselor, după administrarea contrastului iv

La nivelul parenchimului cerebelos s-a evidenţiat o plajă hipodensă nativ şi post contrast, difuz conturată, cu aspect de cerebrită în lobul cerebelos stâng (Fig. B8).

Se mai constată diseminare la nivelul lobului temporal stâng cu evidenţierea unei plaje hipodense nativ şi priză de contrast marginală liniară neregulate sugestivă pentru abces temporal stâng (Fig. B9). Priza de contrast groasă la nivelul cortului cerebelos mai ales de partea stângă. (Fig. B10) Colecție subdurală cu bule aerice, temporală şi pe convexitatea cerebrală (Fig. B11). 


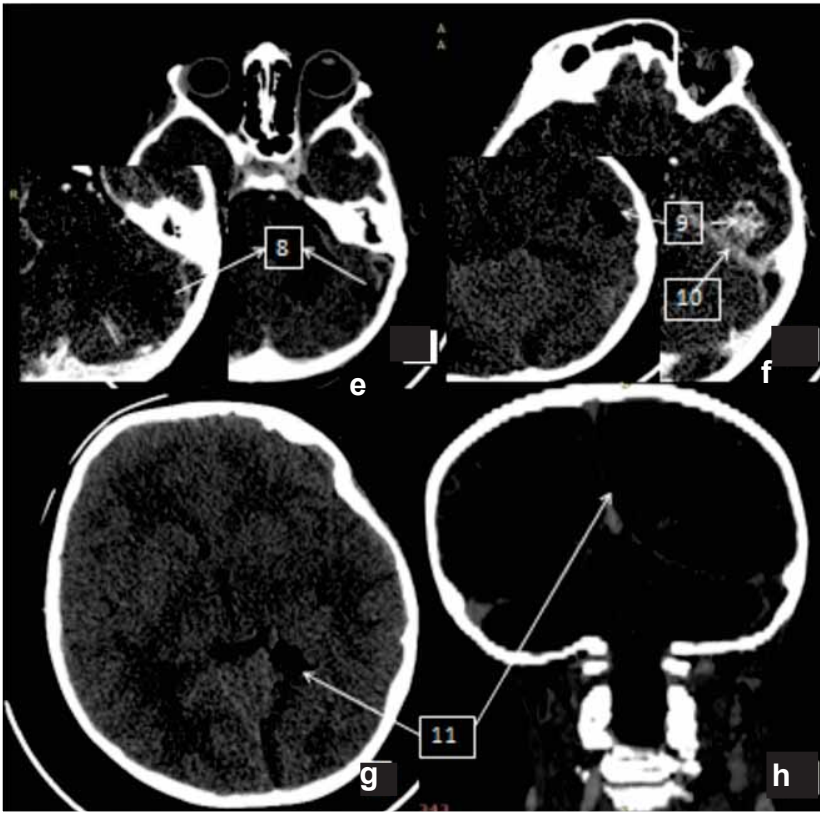

Figura 1B. Examinare CT craniu

e - reconstrucții de $2,5 \mathrm{~mm}$, axiale de fosă posterioară în fereastra de parenchim cu substanță de contrast intravenos; $f$ - reconstrucții axiale nativ şi postadministrarea contrase intravenos la nivel temporal în fereastra de parenchim; $g$ - secțiune axială nativă la nivel supratentorial; $h$ - reconstrucție coronală post injectare contrast intravenos

Edem cerebral difuz la nivelul fosei posterioare cu ştergerea şanțurilor fără semne de angajare la nivelul gaurii occipitale, permițând efectuarea unei puncții lombare.

La puncția lombară se obține LCR xantocrom, proteinorahie $3,135 \mathrm{mg} / 1$ şi la examen citobacteriologic $65 \%$ neutrofile, $35 \%$ limfocite, coci gram pozitivi.

Examenele de laborator evidențiază leucocitoza $32.500 / \mathrm{mm}^{3}$ cu $97 \%$ neutrofile.

Se intervine chirurgical de urgență practicându-se antrotomie $\mathrm{cu}$ evacuarea unei colecții purulente mastoidiene, din care se efectuează examen bacteriologic direct cu evidențierea de bacili gram negativi şi cocii gram pozitivi în lanţuri, iar pe mediile de cultură s-au dezvoltați bacili de proteus mirabilis.

\section{DIAGNOSTIC, TRATAMENT, EVOLUȚIE}

Coroborând toate datele, diagnosticul final a fost: otomoastoidită cronică stângă complicată cu tromboflebită şi tromboză de sinus transvers şi sigmoid extinsă la nivel jugular. Meningo-encefalită cu abcese, cerebelos şi cerebral temporal stâng. Empiem subdural emisfer cerebral stâng.

Schema terapeutică a fost complexă cu tratament multiantibiotic, echilibrare hidrică şi electrolitică, asociat $\mathrm{cu}$ antiinflamatorii, nesteroidiene şi steroidiene, anticoagulante, dar în ciuda eforturilor evo- luția este nesatisfăcătoare cu deteriorarea progresivă a stării generale, stare septică cu comă de grad III şi în final cu exitus prin stop cardio-respirator la 72 ore de la internare.

\section{DISCUȚII}

Otita medie este una dintre cele mai comune infecții din lume la vârsta copilăriei, ce poate duce în 2-6\% dintre cazuri spre complicații supurative intracraniene cu evoluție nefavorabilă, fatală în $8-26,3 \%$ din ele $(2,3)$. Complicațiile apar datorită imaturităţii sistemului imun la copii, deseori după infecții respiratorii superioare ce determină imunosupresie, pot evolua insidios cu o simptomatologie mascată de antibioterapie şi doar bănuită la apariția semnelor neurologice.

Investigațiile imagistice aduc date importante despre: tipul complicațiilor intracraniene, modul de propagare al infecției, în cazul nostru evidențiindu-se leziuni distructive la nivelul urechii medii cu eroziunea peretelui stâncii şi propagarea infecției la nivelul spaţiului Trautman în contact strâns cu sinusul sigmoid, cu formarea unui abces perisinusal, proces ce determină eroziunea peretelui sinusal cu apariţia tromboflebitei locale şi a trombozei intralumenale ce s-a extins la nivelul sinusului transvers şi venei jugulare interne. Prin contactul strâns al abcesului epidural cu meningele, dar şi prin circulația venoasă s-a realizat o diseminare meningeală cu meningită dar şi o colecţie epidurală.

Abcesul cerebelos a apărut prin însămânţare de contiguitate în cerebel printr-o breşă meningeală fiind descoperit în faza de cerebrită cu edem difuz, iar temporal, în faza de abcedare, prin însămânțare venoasă cu evidențierea membranei şi prezența aerului la nivelul său.

\section{CONCLUZII}

În infecțiile otice complicațiile meningo-encefalitice sunt rare, dar când sunt însoțite de semne neurologice pun indicația efectuării unui examen CT în urgență, cu injectare de contrast iv şi reconstrucții cu secțiuni fine, centrate la nivelul stâncilor temporale. În unele cazuri examenul trebuie extins la nivel cervical. El poate stabili dacă există posibilitatea apariției complicațiilor, prin vizualizarea unor leziuni distructive la nivelul urechii medii, pun diagnosticul, stabilesc mecanismele de diseminare, gravitatea complicaţiilor şi topografia lor pentru cel mai bun abord terapeutic.

O bună colaborare între clinician şi radiolog, ca şi accesibilitatea la investigațiile imagistice, implică un diagnostic precoce ce poate salva viața pacientului. 